\title{
Internal Auditors' Intellectual (Knowledge) Dimension in Creating Value for Companies Empirical Study of Jordanian Industrial Public Shareholding Companies
}

\author{
Osama Abdualmunim $\mathrm{Ali}^{1}$ \& Walid Omar Owais ${ }^{2}$ \\ ${ }^{1}$ Accounting Department, Zarqa University, Zarqa, Jordan \\ ${ }^{2}$ Accounting Department, Amman University College for Financial and Managerial Science, Al-Balqa' Applied \\ University, Amman, Jordan \\ Correspondence: Walid Omar Owais, Assistant Professor, Accounting Department, Amman University College \\ for Financial and Managerial Science, Al-Balqa' Applied University, P. O. Box 960958, Amman 11196, Jordan. \\ Tel: 962-77-778-9852. E-mail: waliiid2002@yahoo.com
}

Received: October 4, 2012

Accepted: November 20, 2012

Online Published: December 7, 2012

doi:10.5539/ibr.v6n1p118

URL: http://dx.doi.org/10.5539/ibr.v6n1p118

\begin{abstract}
In recent years, companies in advanced countries have shown an increasing interest in the internal audit profession. This interest is represented in many aspects. Of primary importance is a company's interest in the independent administration of internal auditing and supporting it with all the needed materials, as well as human resources which is an important resource represented by intellectual capital with its capability to add value to companies to enable them to compete in all local and international fields. Therefore, this research attempted to study the importance of this resource for internal auditors in companies. The research concluded that the internal auditors in companies must be continuously concerned with developing their skills and technical experiences (the technical intellectual capital) in order to increase the efficiency and value of companies.
\end{abstract}

Keywords: intellectual capital, knowledge capital, internal audit knowledge, added value

\section{Introduction}

The scandals that large companies were exposed to in the late nineties of the last century, such as those at Enron and World Com among others, shook investors' trust and raised the question of how these great companies allowed these scandals and the consequential collapses to happen. Where were their boards of directors and their executive management? Where were their control systems and their internal and external auditors? The answer is that the internal auditors with their knowledge of intellectual capital play an essential role in helping a board of directors and management to perform the governance tasks which they are responsible for to upgrade the efficiency and to add value for a company.

\subsection{The Problem of the Research}

The research problem is embodied in knowing the answer to the following question: Is there an impact from the intellectual dimension of the internal auditors which will add value for companies?

\subsection{The Importance of the Research}

The intellectual capital issue has recently become an international concern. This issue is a large concern for the owners of companies and shareholders because the maximization of the company's value and the shareholders wealth often depends on the intellectual capital of its members including the internal auditors in order to achieve the company's strategy. Therefore, the importance of this research is to shed light on this important resource and the importance of it being owned by the internal auditors, in order to add value for the company.

\subsection{The Objectives of the Research}

This research aimed at determining the importance of intellectual capital as an important resource that helps internal auditors to maximize and add value for the company in which they work. 


\section{Previous Studies}

The Chalhoub and Beyruti study (2007) aimed to show the competitive impact of intellectual capital on the performance of companies. They studied a sample of companies that work in the Middle East to test five factors that link the organizational performance of the companies with their knowledge management. These factors were: human resources and its growth, market information, strategic coalitions, flow of knowledge to make decisions, and information technology.

The study concluded that all of these factors are suitable, and they are suggested to be used to improve the organizational and intellectual performance of the company. Human resource and developing it, the strategic coalitions and the flow of knowledge to make decisions are considered the most important conditions for an organization's success in all fields.

The Juma' study (2006) aimed at determining the development trends of knowledge in the internal auditing profession in scientific and professional contexts, and in the scientific practice to determine the internal auditor's duties in Jordanian organizations. One hundred and eleven companies were tested to measure the extent of the top management's perception to develop knowledge in the internal auditing profession.

The study showed that internal auditors in the twenty first century are required to audit everything in the company, and the internal audit profession now belongs to an integrated structure of knowledge, which gives it the full potential of the profession. Also, the banking sector in Jordan has been the biggest sector committed to establishing an internal auditing administration, but it has the least awareness in developing the knowledge of the internal audit profession.

The report of Skyrme (2003) sought to demonstrate the increased interest in the measurement techniques of knowledge and intellectual capital where a company's balance sheet usually showed a partial idea about their reality and sometimes included misleading information. Therefore, it was necessary to have adequate and necessary procedures to arrive at the real value of companies through the visions of the institutional governorship used for intellectual capital.

The report highlighted an important role of a company which is to know the effect of intellectual capital as an intangible resource. Sometimes, there are inaccuracies in the measurement and disclosure process of intellectual capital which can influence the internal and external auditor's judgments. Therefore, there should be a measurement model that addresses the accounting and legal matters for the methods of disclosure.

Catherine, Jay and Priscilla (2002) showed the importance of intellectual capital as the value creator of a company and indicated how intellectual capital participates in the evaluation and measurement of a company's system. The study offered many recommendations, most importantly determining the importance of internal auditing when evaluating and measuring a company's intellectual capital and showing its extent as an important tool to measure and evaluate the special value of any company.

\section{The Research's Methodology}

The researchers will depend on the descriptive analytical approach for this research, where the necessary data for the research was obtained from primary sources and secondary sources.

\subsection{The Primary Sources}

The primary source of information came from a questionnaire prepared and distributed to the internal auditors from a sample of Jordanian industrial shareholding companies. After that, the data was collected and analyzed by using the statistical package for social sciences in order to test the validity of the research's hypothesis.

\subsection{The Secondary Sources}

The secondary source of information was from books, university dissertations, scientific researches and reports and magazines in order to build the theoretical frame for the research and to achieve its objectives.

\section{The Theoretical Side}

The financial scandals at the end of the twentieth century showed the decisive role that a board of directors plays in enforcing and strengthening a company. They bear the final responsibility of the internal control in their organizations. Moreover, intellectual capital plays an essential role in helping these boards to perform the governance task which they are responsible for, upgrading the company's performance and adding value.

\subsection{Defining Internal Audits}

Internal audits can be defined as an independent, asserting consultancy activity designed to add value and improve the organization's operations by helping them to achieve their purposes through an organized and 
controlled approach, in order to improve and evaluate the efficiency of risk management, control and governance operations (Gramling \& Hermanson, 2006).

This definition of internal audits shows that the role of the board of directors is emphasized in securing the effectiveness of the internal audit frame in the organization, which leads to helping the board to perform its provenance responsibility towards its organization. This emphasizes the essential role which the internal auditor can play to help the board of directors to guarantee the internal audit adequacy to become an integral part of the organizational provenance of the organization.

The effectiveness of the board of directors and the top management is increased by perceiving the importance of the auditing task, by guaranteeing the independency and solidity of the auditors that work with the full authority of the management, and by investing in their conclusions in a timely manner (Cattrysse, 2005).

In order for the internal auditor to be able to "add value" to the organization, it must achieve a real cooperation between itself and the management. This can be demonstrated through the fact that the internal auditor must take into consideration in the annual auditing plan any risks or matters that concern the control diagnosed by the management.

Demand on this profession stems from the urgent need to provide an independent investigation means to limit fraud and accounting record mistakes in the organization and to protect the assets of the various organizations.

The writers and researchers in this profession confirm that its existence has extended over 6000 years, as there is a cogent evidence that there were official systems for recording and verification, used at that time in the near east regions (Saudi Organization for Certified Public Accountants (SOCPA), 2004, p105).

Interest in the internal audit began to increase in Europe, particularly, in the eighteenth century as a result of the appearance of too many cases of manipulation and fraud in many companies.

With the transfer of the European systems of accounting and auditing to the U.S.A. and other western countries as their businesses activities grew, the real trend began towards the necessity for the existence of an independent control job inside any company or organization. Because the interests of a company's management was pivoting mainly on the necessity of protecting the company's assets and on keeping precise financial records along with a commitment to the procedures that exist to limit manipulation and fraud cases, this profession is considered an extension of the external auditing profession.

This narrow view of internal auditors' work pushed them to concentrate on the financial side only among the various companies' activities. Therefore, their role was limited, and there was no need to establish an independent division or department for the internal audit within a company's organizational structure.

Due to the increase of a company's activities, its size and complication of its operations, the interest in the management's control function has increased. This has in turn increased the need of the internal audit profession as a control mechanism that helps management to perform its control task efficiently and effectively through evaluating the extent of the commitment to the policies and procedures to protect the company's assets, verifying the accuracy and completion of its accounting records and evaluating its operating efficiency in addition to the efficiency and honesty of its workers. This leads to the necessity of acknowledging the vital role the profession plays as a control job that covers all the financial and operational sides of a company or institution.

As a result of the economic collapse and bankruptcy cases in American companies in the 1940s, internal auditing as a profession which enables a company to achieve its purposes began to be recognized. Consequently, the Institute of Internal Auditors in the U.S.A was established with the aim to develop internal auditing as a recognized profession.

\subsection{Nature of Internal Audits}

The nature of internal audits is specified according to their role in enforcing the controlling job of the company's managements. This trend called for improving the control performance of the management. This trend can be attributed to three factors (Saadani, 2009).

- Increase of the failure of companies and bankruptcy.

- The change of the company's ownership forms.

- The changes in the environment in which the companies work.

It has been noted in recent years that many huge companies have collapsed, especially in the U.S.A. This attracted the attention of legislators, researchers and others who are interested in the business and economy fields. Many studies have been conducted to determine the reasons for such collapses; the conclusion was that 
the main reason for the collapses is the weakness of the control performance, due to the deficiencies in the board of directors in addition to the low quality of the auditing committee's performance or absence of the internal audit job in such companies.

On the other hand, important changes in the form of ownership occurred, especially the shareholding companies as a result of transforming the shares ownership from the individual investor to the investment organizations such as investment funds, banks and others. This led to the concentration of ownership in the hands of a few investors who effectively influenced the company's board of directors. Those investors began to call for the necessity of changing the administrative, procedural and control methods used by the companies to achieve the protection required for their interests.

\subsection{Code of Ethics}

The Code of Ethics states the principles and expectations governing the behavior of individuals and organizations in the conduct of internal auditing. It describes the minimum requirements for conduct, and behavioral expectations rather than specific activities. (The Institute of Internal Auditors (IIA), 2002a)

The purpose of the Institute's Code of Ethics is to promote an ethical culture in the profession of internal auditing. A code of ethics is necessary and appropriate for the profession of internal auditing, founded as it is on the trust placed in its objective assurance about governance, risk management, and control.

The Institute's Code of Ethics extends beyond the definition of internal auditing to include two essential components:

- Principles that are relevant to the profession and practice of internal auditing.

- Rules of Conduct that describe behavior norms expected of internal auditors. These rules are an aid to interpreting the principles into practical applications and are intended to guide the ethical conduct of internal auditors.

\subsubsection{Code of Ethics - Principles}

The Institute of Internal Auditors issued a special charter for the ethical conduct which the auditor must adhere to, which consisted of the following principles (IIA, 2002a, P 1-3):

\subsubsection{Integrity}

The integrity of internal auditors establishes trust and thus provides the basis for reliance on their judgment.

Rules of Conduct

Internal auditors:

- Shall perform their work with honesty, diligence, and responsibility.

- Shall observe the law and make disclosures expected by the law and the profession.

- Shall not knowingly be a party to any illegal activity, or engage in acts that are discreditable to the profession of internal auditing or to the organization.

- Shall respect and contribute to the legitimate and ethical objectives of the organization.

\subsubsection{Objectivity}

Internal auditors exhibit the highest level of professional objectivity in gathering, evaluating, and communicating information about the activity or process being examined. Internal auditors make a balanced assessment of all the relevant circumstances and are not unduly influenced by their own interests or by others in forming judgments.

Rules of Conduct

Internal auditors:

- Shall not participate in any activity or relationship that may impair or be presumed to impair their unbiased assessment. This participation includes those activities or relationships that may be in conflict with the interests of the organization.

- Shall not accept anything that may impair or be presumed to impair their professional judgment.

- Shall disclose all material facts known to them that, if not disclosed, may distort the reporting of activities under review.

\subsubsection{Confidentiality}

Internal auditors respect the value and ownership of information they receive and do not disclose information 
without appropriate authority unless there is a legal or professional obligation to do so.

Rules of Conduct

Internal auditors:

- Shall be prudent in the use and protection of information acquired in the course of their duties.

- Shall not use information for any personal gain or in any manner that would be contrary to the law or detrimental to the legitimate and ethical objectives of the organization.

\subsubsection{Competency}

Internal auditors apply the knowledge, skills, and experience needed in the performance of internal audit services.

Rules of Conduct

Internal auditors:

- Shall engage only in those services for which they have the necessary knowledge, skills, and experience.

- Shall perform internal audit services in accordance with the International Standards for the Professional Practice of Internal Auditing (Standards).

- Shall continually improve their proficiency and the effectiveness and quality of their services.

\subsection{Definition of Intellectual Capital}

This subject is relatively new in administration and accounting theories. The interest of this topic began in the 1990 s, but it is still in the development, building and exploration stage. Therefore, there is no clear agreement on its concepts.

Prahalad and Hamel (1994) identified intellectual capital as a unique ability by which organizations and companies supersede their competitors through the integration of their various skills that increase the added value to all the investors and it is one of the competitive relevancy resources.

Webster (1995) ascertained it as the character of the transforming leaders, their ability to successfully transform technology into manufacturing in a manner that builds organizations and companies in the world of competition for a long period.

Youndt, Snell, Dean and Lepak (1996) characterized intellectual capital as the distinguished intellectual ability enjoyed by a limited number of individuals who work in companies and institutions that enables the companies and institutions to increase their productivity and to achieve higher levels when compared with similar institutions.

Stewart $(1997, \mathrm{p} 2)$ identified it as the knowledge that can be employed, i.e., the knowledge cannot be a capital unless it is found and employed in a way that can be used in favor of the companies or organizations.

At the same time, Enders (1997, p. 96) labeled it as the knowledge of assets that transform technology from unique research into manufacturing with a distinguished success, which is considered the main indicator and pivot for success of any company or organization on the local or international level.

Edvinsson and Malone (1997, p. 21) presented a metaphorical example of the intellectual capital concept. They imagined the organization as a tree where its plans, seasonal and annual reports, its publications and various documents are the trunk of the tree and its branches and leaves are the things that the investor looks at for its ability to produce fruits. Judging the tree's ability, though, according to what is viewed above the surface of the ground (the trunk, branches and leaves) is not wise because there is an important part of the tree under the ground. Therefore, one cannot judge the tree correctly without checking the roots, where there might be a disease or mold in the ground, which definitely affects the future of the tree although it appears sound at the moment. The intellectual capital is like the roots of the tree, and to judge the future performance of the tree, one must focus on the reality and future of the intellectual capital with all its elements.

Both researchers saw intellectual capital as a continuously renewable quality because of the integration of the fast surrounding environment with all parts of the company or organization beginning with the integration of the skills and experiences of all the company's members to the advantage of dealing with special suppliers and the quality of goods and services.

Therefore, it is not possible to provide a certain feature for this important resource, where its possession is one of the competitive advantages for a company that can raise the company's value locally and internationally. The 
researchers see that the internal or external auditor must possess this important resource in order to increase the value and efficiency of the company being audited.

\subsection{Internal Auditing under Organizational Behavioral Theories and Their Influence on Intellectual Capital}

Internal auditing as a profession has appeared in an organizational frame and under systems controlled by certain theories and philosophies. Internal auditing can be seen according to its relationship with the organizational behavior from two views:

First, as internal auditing is an organizational cell, it should be rationalized according to the project's system.

Second, it is a means that helps to achieve the continuous balance of the system through the evaluation and feeding of information that helps to correct any imbalance in the system.

The following are the most important organizational theories of internal auditing (Youssef, 1986, p. 198-226).

\subsubsection{The Classical Theory of Organizational Behavior}

This theory is based on many assumptions revolving around individuals' behaviors that are influenced by the opportunist philosophy. This means that individuals calculate the benefits of a behavior's alternatives, and based on that they will determine their behavior by selecting the alternative behavior which accomplishes the maximum benefit for them.

This theory is based on the following assumptions:

- The economic motives are the base of individuals' behavior, as they behave according to the best benefits they can obtain.

- As the organization controls the economic motives, it can also control individuals' behavior.

- Individuals' feelings must be allowed in calculating their personal benefits when they select the alternatives.

- The organization must be organized in a way that allows controlling individuals' feelings which might influence their behavior.

The internal auditing under this theory is thinking about how to help management control the human and financial resources to accomplish profit maximization.

The context of internal auditing is represented in the verification of the adequacy of the control system over the financial resources in order to protect the company's assets, to achieve the best of the individuals by guaranteeing that they don't exploit the available resources in their favor and through the organizational administration to insure adequacy of the control of the compliance between the workers objectives and the organizational objectives to maximize the profits. In addition, the verification of the correctness and precision of the data that come from the lower levels in the organization insures the nonexistence of bias for personal purposes and teaches individuals to acquire rational behavior departing from idleness and avoiding emotions, through the continuous clarification of good performance with rewards and punishment in the case of unsatisfactory performance.

Therefore, under this theory internal auditors should own the special features that enable them to perform difficult tasks, and on the technical side, the workers must be trained under an organizational environment that is controlled by the beneficial philosophy.

Because internal auditors work beside the administration, they must be its eyes and ears in the organization, and they should do their best to detect fraud and mistakes as well as the inefficiency of the workers. Therefore, they must possess the personal features that enable them to do that. For example, they should have the ability to notice and connect between concepts, observations and critical ability.

Despite the authority granted to the internal auditing, it remains a consultancy authority from the official side, because the internal audit job is a service job.

Both researchers see that this theory might give clear evidence that internal auditors must own unique elements represented by intellectual capital, and they must own the features that enable them to do their job efficiently. They should have the ability to rationally criticize and explain their concepts and observations. Regarding that, internal auditors must possess the intellectual capital and must have the character that enables them to do their job efficiently.

\subsubsection{Human Relationships and Human Resources Theory}

This theory says that materialistic needs can control the workers' thinking regarding their performance. However, there is another type of need that controls individuals in the organization, such as the need for 
individuals to be loved by their colleagues, and that they must have a social position in the organization. Social needs are the most urgent to be satisfied and not the economic needs alone.

Therefore, the most important assumptions of this theory are as following:

- Individuals' motives can be divided into layers in a pyramidal form, where the physiological needs come first, followed by social needs and the need for independency and, finally, at the top of the pyramid comes the need for self-realization.

- Individuals in an organization seek to grow and become aware of the requirements of their jobs.

- Individuals in an organization are able to realize self-control and to motivate themselves with internal motives. Therefore, external incentives are considered threatening to them and reduce their ability to let them grow.

- There is no conflict between the need for self realization of individuals and their effective performance.

The objectives of internal auditing under this theory are to help management and individuals to know the groups of behavior types and to show the challenging features in business, to help in controlling the financial resources, not for the benefit of top management only, but for the benefit of individuals also in order to fulfill individuals' objectives and the organizational objectives at the same time.

The context of internal auditing under this theory is represented by the adequacy of the control methods on the materialism resources, protection of the organizational assets, verification of the data correctness needed by the management and the individuals in the organization, verification of the adequacy of the controls in the organization to sustain the compliance between the individual's objectives and the organizational objectives, continuous evaluation of the objectives, assistance in developing the thoughts of management by objectives, and participation in teaching individuals the necessary skills for communication, preparing reports and plans and making decisions.

Here, auditors should have the social skills that enable them to approach individuals and groups in a way that enables them to satisfy their social needs and to help them to show their creative capacities and practice self control. Also, the auditors must possess the ability to adapt with all the organizational levels.

Auditors' authority must be consultative, i. e, they should present pieces of advice to all levels in the organizations. There should also be a democratic method in executing the auditing process, and the individuals should participate with the internal auditors in all auditing stages.

Both researchers see that this theory shows the necessity of auditors possessing intellectual capital elements. It also shows the importance of this theory as one of the main pillars to take the organization to the highest levels of organizational provenance.

\subsubsection{Modern Organizational Behavior Theory}

This theory showed that individuals in an organization are not individuals just seeking simple economic benefits as mentioned in the classical theory, nor are they simply individuals with social needs that the human relationships assumed. Also, individuals are not controlled by just motives for self realization according to human resources, but individuals have various motives, and they are controlled by various motives different from individual to individual and from moment to moment.

Therefore, the most important assumptions of the modern theory are as follows (Youssef, 1986, p. 219):

- Individuals' motives are not only complicated but different. They belong to a group of motives in a pyramidal form, different from time to time and from one situation to another. Moreover, individuals' motives interact with each other and form a complicated form.

- Individuals are able to acquire new and creative motives through practicing their work in the organization.

- Individuals' motives in various organizations and in different levels in an organization are different.

- Individuals can be productive in an organization based on satisfying various needs and motives.

- Individuals can react to various strategies, according to indivduals' motives, abilities and natures, and the type of work they perform.

The objectives of internal auditing under this theory are confined to the continuous diagnosis and evaluation of financial and administrative matters, in order to enable management to apply the appropriate planning and control policies and to follow their execution. It also enables individuals in the various levels in the organization to relatively satisfy their various needs and desires.

The context and specialization of the internal audit cover all the contexts and specializations of the previous 
theories, which are expected to be flexible and proportionate with the situation requirements, i.e., the main feature of the internal auditor is to be flexible and fast in adapting. Therefore, there is no specific detailed specializations, but there are wide lines for these specializations that enable them to move through these lines.

The researchers also see that internal auditors' tasks are wider, compared with the other theories, where the auditors mostly have one form, but according to this theory, their role is different according to the circumstances. For example, if they comply with the classical theory, they will be biased in favor of top management, i.e, they will be the management's eye at the lower managerial levels, and their main task will be to provide protection to the organizational assets and resources against the expected behavior of the organization. However, if their position complies with the human relations theory, then their role will be beside the workers more than the top management. Their task will be to satisfy their social needs. Therefore, their focus on protecting the organization's assets and resources will be decreased because they suggest that the individuals appreciate the responsibility and never work against the organization. This requires that auditors should be flexible to deal with the various situations, and they should have thinking and communication skills (they should possess intellectual capital).

The authority of internal auditors will stay consultative, and their actual authority might differ from formal authority from one organization to another according to the circumstances, the leadership type, the division's location at the organizational structure, and the type of leaders' features in the organizations.

From the three above mentioned theories, it can be concluded that the internal audit is a main component and important support in any organization and the people who do this job must own the intellectual capital to take the organization to the highest level of creativity.

\subsection{Role of the Internal Audit to Add Value to a Project}

A project's strategy can be considered the integration between the internal auditing and the value added concept at an organization which aims at creating an added value for the owners or the other stakeholders. This concept provides the objectives of an organization. The value is provided through developing products and services by using productive resources. The auditors attempt to understand and evaluate the risks and develop important conceptions for improved operations that might be useful for organizations.

Such important information might be in a form of consultancies and written advice or through other products which must be taken to the management or the concerned employees. Added value is a main decisive condition for every organization. The traditional way to arrive at the added value was by the project which transforms inputs through operations to sell the product in the market with a value above the input costs in the long run (Kotlarski, 2006).

As clarified above, the internal audit includes two types of activities which are confirmation and consultancy. These two activities focus on adding value. Confirmation services are one of the main tasks of internal auditing that is based on three pillars: risk management, control, and governance.

Confirmation services are the objective test of the evidence in order to provide an independent evaluation of the risk management, control and governance operations for the project while the consultancy represents the other services except the confirming services provided to help the management to achieve their objectives.

The three standards (risk management, control and governance) are considered close to each other, especially since there is a close relationship between control and risk management. The internal audit will lead a company to improve operations, add value, and achieve the objectives. However, this cannot be accomplished unless the internal auditors own the intellectual knowledge so they can improve the efficiency of their companies.

\section{The Practical Side}

\subsection{The Research's Hypothesis}

The research is based on the assumption that:

There is no impact on the intellectual dimension for the internal auditors to add value for companies with a statistical importance at the level of significance $(\propto \leq 0.05)$.

\subsection{The Research's Sample}

The sample was selected from internal auditors who have a lot of experience in the auditing field in Jordanian industrial public shareholding companies listed on the Amman Exchange.

\subsection{Analysis of the Demographic Characters of the Sample's Members}

A questionnaire was distributed among the experienced auditors and the results are presented in table 1. 
This table shows that the surveyed participants who work as internal auditors were $77.8 \%$ of the sample, so the questionnaire touched the core of their work and supports the answers of the questionnaire. Also, they owned the appropriate scientific qualifications, where $88.9 \%$ of the participants hold a bachelor degree, and $77.8 \%$ of them had experience more than 16 years. This means that there is a consistency between the scientific situation and the professional experience between the members of the sample.

Table 1. Sample members according to the demographic variables

\begin{tabular}{llll}
\hline Variable & Class & Number & $\%$ \\
\hline Profession & Audit manager & 8 & 17.8 \\
& Internal auditor & 35 & 77.8 \\
& Assistant auditor & 2 & 4.4 \\
Qualification & Total & 45 & 100 \\
& Bachelor & 40 & 88.9 \\
& Master & 5 & 11.1 \\
& PhD & 0 & 0 \\
Experience & Professional certificate & 0 & 0 \\
& Total & 45 & 100 \\
& $5-10$ years & 6 & 13.3 \\
& $11-15$ years & 4 & 8.9 \\
& 16 years and more & 35 & 77.8 \\
\hline
\end{tabular}

\subsection{Results of Testing the Hypothesis}

Results of table 2 show that the evaluation of the study's sample was high with means that ranged between 3.89 -4.22 .

Table 2. The mean and standard deviation of the intellectual (knowledge) dimension of internal auditors

\begin{tabular}{|c|c|c|c|}
\hline Statements of the questionnaire & Mean & Standard deviation & Result \\
\hline $\begin{array}{l}\text { 1. The internal auditors, with what they own of skills and technical knowledge (intellectual } \\
\text { capital), have an influence on the company's value in competing markets }\end{array}$ & 3.89 & 0.97 & High \\
\hline $\begin{array}{l}\text { 2. The internal auditors must influence the effectiveness and efficiency of the internal control in } \\
\text { the company, with their intellectual capital and preparation of reports about the company }\end{array}$ & 3.97 & 0.55 & High \\
\hline $\begin{array}{l}\text { 3. The internal auditors with what they process of skills and technical knowledge (the intellectual } \\
\text { capital) must influence the evaluation of the control that accompanies the information technology } \\
\text { in the company }\end{array}$ & 4.15 & 0.85 & High \\
\hline $\begin{array}{l}\text { 4. The clear vision of the company enables the internal auditors in the company to develop their } \\
\text { inspiration power to go towards the objectives through encouraging and supporting the } \\
\text { establishment of a team that owns the technical skills and the knowledge (the intellectual capital) } \\
\text { to improve and increase the company's value }\end{array}$ & 4.11 & 0.87 & High \\
\hline $\begin{array}{l}\text { 5. The internal audit department with its technical knowledge (intellectual capital) can prove that } \\
\text { the documentation process which they have managed added valued to the company }\end{array}$ & 4.12 & 0.78 & High \\
\hline $\begin{array}{l}\text { 6. The responsibility of the internal auditors. with their skills and knowledge, is to select the } \\
\text { extent of the commitment to control procedures and present recommendations necessary to } \\
\text { improve them which preserves the company's value }\end{array}$ & 4.10 & 0.80 & High \\
\hline $\begin{array}{l}\text { 7. The head of internal audit department with what he/she knows (intellectual capital) must work } \\
\text { to develop and maintain the internal audit program's quality in the company and to continuously } \\
\text { control its efficiency to increase the company's value }\end{array}$ & 3.96 & 0.75 & High \\
\hline $\begin{array}{l}\text { 8. The internal audit department with what it knows (intellectual capital) must test the adequacy } \\
\text { of the internal control systems in the company with the aim of determining if the system } \\
\text { established provides a reasonable assurance that the company's objectives have been } \\
\text { accomplished in an efficient economic way }\end{array}$ & 4.07 & 0.84 & High \\
\hline $\begin{array}{l}\text { 9. The internal auditors in the company must be keen to develop their skills and technical } \\
\text { experiences (the intellectual capital) in order to increase the company's efficiency and value }\end{array}$ & 4.22 & 0.59 & High \\
\hline The general mean and standard deviation & 4.07 & 0.50 & High \\
\hline
\end{tabular}

Statement (9) ranked the first with a means of 4.22 which states that the internal auditors must be keen to develop their skills and technical experience (the intellectual capital) in order to increase the company's efficiency and its value. This means that the auditors should work to extend their scientific perceptions and their 
experience and to attempt to follow up every modern issue in their jobs to increase their companies' values, locally and internationally.

While statement (1) which states that the internal auditors, with what they own of skills and technical knowledge (intellectual capital), have an influence on the company's value in the competing markets, came in last with a mean of 3.89 and standard deviation of 0.97 .

\subsection{Testing the Research Hypothesis}

To test the correctness of the hypothesis, the researchers used the simple linear regression analysis method. Table 3 shows the results of measuring the intellectual (knowledge) dimension impact of internal auditors on adding value to companies.

Table 3. Results of the simple linear regression analysis to measure the intellectual (knowledge) dimension impact of internal auditors on adding value to companies

\begin{tabular}{|c|c|c|c|}
\hline & $\begin{array}{l}\text { Regression } \\
\text { coefficient (B) }\end{array}$ & $\begin{array}{l}\text { Calculated (t) } \\
\text { value }\end{array}$ & $\begin{array}{l}\text { The statistical significance } \\
\text { p-value }\end{array}$ \\
\hline The constant (B) & 2.184 & 5.456 & 0.000 \\
\hline The intellectual (knowledge) dimension of internal auditors & 0.471 & 4.820 & 0.000 \\
\hline Calculated (f) & 23.234 & & \\
\hline Significance of (f) & 0.000 & & \\
\hline Simple correlation coefficient (R) & 0.459 & & \\
\hline Explanation coefficient (R2) & 0.211 & & \\
\hline
\end{tabular}

From table 3 it is clear that the significance of the regression coefficient (B) for the intellectual (knowledge) dimension for the internal auditors must create an impact with a statistical significant at level of significance ( $\propto \leq 0.05$ ). The intellectual (knowledge) dimension of the internal auditors is supported by the (t) value that equals to 4.820 and the p-value for the intellectual (knowledge) dimension for the internal auditors is less than the significance level $(\alpha \leq 0.05)$. Based on the results above, the null hypothesis (H0) will be rejected and the alternative hypothesis (H1) will be accepted which states that there is an impact with statistical significant at ( $\propto \leq 0.05$ ) for the intellectual (knowledge) dimension for internal auditors in adding value to companies.

\section{The Results}

There is a need to highlight Jordanians auditors as a safety value for companies under scrutiny to reach the leadership at the local and global level.

Jordanian accountants and auditors need complex legal work, workshops and courses for auditors that focus on the concepts and methods of measurement and exports of intellectual capital as an important resource to create real value for companies to access innovation and global competitiveness.

The intellectual capital concept is continuously renewable because of the changing environment of the company; therefore, it is still at the development stage, it expresses in particular the knowledge assets (the intangible assets of the company). Intellectual capital helps to evaluate the risks and to create the real value of the company; it might be the real key for prosperity of the company in the future.

The objective of the internal audit currently is embodied in increasing the company's value and improving its processes in addition to evaluating and improving the control efficiency in the company.

Companies can create value for themselves by employing auditors who possess the knowledge and the intellectual skill which help them to adopt their public strategies and execute their technical activities. Internal auditors can add value to the company by creating real cooperation with the management, and this can be emphasized by taking into consideration any risks noticed by the management when they set up the auditing plan.

The auditors must adopt the most important factor (the intellectual factor) in creating added value to companies, and the auditors must be keen continuously to increase the company's value. The mean of this factor was 4.22 which was the highest in this study, and its standard deviation was 0.59 .

\section{Recommendations}

The management of shareholding companies needs to understand and grasp intellectual capital because it has special value for companies that increase their efficiency so they can excel locally and internationally.

The interest in intellectual capital and managing it like any asset in the company needs to be increased because it 
is important for the strategic concern of current companies. They must take inactive capabilities and activate them, establishing an administration that will add to their value by investing in the intellectual capital.

Intellectual capital for any shareholding company needs to be created by allowing internal auditors and employees to present their opinions and propositions about developing the work in their companies and encouraging direct dialogues between them and management in order to develop creative ideas which eventually will increase the company's value and efficiency.

Internal auditors must have the following capabilities and features to increase the company's value: creative and critical thinking; the management and evaluation of risks; qualitative and statistical inference; early communication; persuasive powers; strong sense of ethics; the ability to understand, adopt, analyze, and evaluate strategies; complete knowledge of modern information technology; and the ability to judge and give neutral technical opinions.

Intellectual capital is an important resource for internal auditors because when this resource is highlighted and evaluated, it becomes an essential tool to measure and evaluate a special value of every company.

\section{References}

Cattrysse, J. (2005). Reflections on Corporate Governance and the Role of the Internal Auditor. Roularta Media Group. http://dx.doi.org/10.2139/ssrn.485364

Chalhoub, M. S., \& Beyruti, N. M. (2007). Developing Competitive Advantage through Knowledge Management and Intellectual Capital. Arab Journal of Administrative Sciences, Kuwait University, 14(3), 135 .

Edvinsson, L., \& Malone, M. S. (1997). Intellectual Capital: Realizing Your Company's True Value by Finding Its Hidden Brainpower. New York: HarperCollins.

Endres, A. (1997). Improving R\&D Performance: The Juran Way. New York: John Willey \& Sons Inc.

Gramling, A. A., \& hermanson, D. R. ( 2006 ). What role is your Internal Audit function playing in corporate governance. Internal Auditing Magazine, 21(6), 37-39.

Juma', A. H. (2006). Perception of Senior Management for the Development of Knowledge in the Profession of Internal Auditing and Its Impact on the Internal Auditor's Role: An Analytical Study Test in the Jordanian Business Organizations. Arab Journal of Administrative Sciences, Kuwait University, 13(1).

Kotlarski, M. W. (2006). Internal audit and Its role in creating Corporate Value. Introduction. Warsaw School of Economics, Warsaw, 19th march, pp 4-10.

Marr, B., Schiuma, G., \& Neely, A. (2004). Intellectual capital - defining key performance indicators for organizational knowledge assets. Business Process Management Journal, 10(5), 551-569. http://dx.doi.org/10.1108/14637150410559225

Prahalad, C. K., \& Hamel, G. (1994). Strategy as a field of study: Why search for a new paradigm? Strategic Management Journal, 15(s2), 5-16. http://dx.doi.org/10.1002/smj.4250151002

Saadani, M. H. (2005). Internal auditing in the framework of corporate governance from the perspective of internal audit services, research presented in the first scientific conference: Internal Audit in the context of corporate governance. The Arab Administrative Development Organization (ARADO), Cairo (24-26) in September.

Saudi Organization for Certified Public Accountants (SOCPA). (2004). Draft Internal Audit Standards and Rules of Professional Coduct. Retrieved from: http://www.socpa.org.sa

Skyrme, D. (2003). Measuring Knowledge and Intellectual Capital. Retrieved from: $\mathrm{http}: / /$ www.skyrme.com/pubs/measures $2 . \mathrm{htm}$

Stewart, T. A. (1997). Intellectual Capital: The New Wealth of Organizations. New York: Doubleday Currency.

Subramaniam, M., \& Youndt, M. A. (2005). The influence of intellectual capital on the types of innovative $\begin{array}{llll}\text { capabilities. Academy of Management } & \text { Journal, 48(3), }\end{array}$ http://dx.doi.org/10.5465/AMJ.2005.17407911

The Institute of Internal Auditors (IIA). (2002a). Code of Ethics. Retrieved from: https://na.theiia.org/standards-guidance/mandatory-guidance/Pages/Code-of-Ethics.aspx

The Institute of Internal Auditors (IIA). (2002b). International Standards for the Professional Practice of Internal Auditing

(Standards).

Retrieved

from: 
https://na.theiia.org/standards-guidance/mandatory-guidance/Pages/Standards.aspx

Usoff, C. A., Thibodeau, J. C., \& Burnaby, P. (2002). The Importance of Intellectual Capital and Its effect on Performance Measurement Systems. Managerial Auditing Journal, 17(1/2), 9-15. http://dx.doi.org/10.1108/02686900210412180

Walkman, D. (2002). Internal auditing standards. research presented at the Scientific Conference IV: accounting and the challenges of globalization. the Association of Certified Public Accountants. Amman: Jordan, (24-25) September.

Webstar, A. C. (1995). Transformational Leadership Through Intellectual Capital: Three Case Studies of Elementary School Principals. University of Colorado at Denver.

Youndt, M., Snell, S., Dean, J., \& Lepak, D. (1996). Human resource management, manufacturing strategy, and firm performance. Academy of Management Journal, 39(4), 836. http://dx.doi.org/10.2307/256714

Youssef, M. M. K. (1986). Lessons and Research in Audit. Dar Al Fikker Al Arabi. Cairo: Egypt. 